\title{
Evaluation of Botanicals against Cotton Mealy Bug, Phenacoccus solenopsis Tinsley (Psuedococcidae: Hemiptera)
}

\author{
K. Bharathi* and N. Muthukrishnan \\ Department of Agricultural Entomology, Agricultural College and Research Institute, \\ Madurai 625 104, Tamil Nadu, India \\ *Corresponding author
}

\section{A B S T R A C T}

Keywords

Botanicals,

FORS, Mealy bugs,

Phenacoccus

solenopsis.

Article Info

Accepted:

10 October 2017

Available Online:

10 December 2017
Experiments were conducted to evaluate the efficacy of different kind of botanicals and fish oil rosin soap (FORS) against mealy bug, Phenacoccus solenopsis Tinsley (Psuedococcidae: Hemiptera) at laboratory and field condition. Results revealed that application of FORS @ 2.5 per cent, neem oil @ 3 per cent and NSKE @ 5 per cent were found to be the most effective treatments and recorded low mean population of mealy bugs viz., $5.5,7.5,9.3$ and 5.9, 7.4, 8.0 adults/crawlers per $5 \mathrm{~cm}$ apical shoot with the per cent reduction of $85.3,79.8,74.9$ and 84.0,79.8, 78.2, respectively in both preliminary and confirmatory field trials. FORS @ 2.5 per cent with increased yield of 61.4 and 68.1 per cent in both preliminary and confirmatory field experiments respectively compared to untreated check.

\section{Introduction}

Cotton mealy bug, Phenacoccus solenopsis Tinsley (Psuedococcidae: Hemiptera) invasion was earlier recorded on cotton in India by Dhawan et al., (1980 and 2009), Patel et al., (1990), Muralidharan and Badaya (2000). In recent times, $P$. solenopsis has rise above the status of a key and severe pest in the whole cotton growing areas of India and the yield loss of 14 per cent has been estimated (Anon., 2005). Besides mealy bugs release toxic substance causing curling and drying of leaves and thus drastically decrease kapas yield (Mani, 1989). Continual increase of mealy bugs on cotton and other plants has started threatening the economical production of many crops. In India, management strategies like use of chemicals and other methods of using cultural practices, mechanical tools, pheromones, resistant varieties, and biologicals have been used generally to alleviate all economic cotton pests including mealy bugs. It is evident that extensive use of pesticides on cotton resulted in 50 to 55 per cent of total pesticide consumption in India (Jayaraj, 1999 and Kairon et al., 1999). Moreover, number of sprays has been increased from 6-8 in 1990's to $12-20$ in 2000's (Dhawan and Simwat, 2000) which constitutes more than 25 to 40 per cent of the total production costs. Thus, 
over dependence and indiscriminate use of potent and wide spectrum pesticides on cotton have lead to induced pesticide resistance (Nagata, 1982), pest resurgence (David, 1981; Reissig et al., 1982), environmental pollution, higher mammalian toxicity (Ayyangar and Nagasambangi, 1990), toxic effect on nontarget organisms (Tewari and Krishnamoorthy, 1983; Lim et al., 1986; Kao and Tzeg, 1990), secondary pest outbreak, pesticide poisoning (Singh and Dhaliwal, 1983) and public concern on food safety, and interruption in ecocycles and biodiversity (Bellows, 2001). In this context, ecologically viable and economically feasible non chemical pest management methods can play a viable alternative against $P$. solenopsis in cotton ecosystem. Hence the present study was aimed to evaluate the botanicals and FORS against $P$. solenopsis under laboratory and field condition.

\section{Materials and Methods}

\section{In vivo bioassay}

Cotton Mealy bug, Phenacoccus solenopsis was mass cultured on sprouted potato tubers using standard method (Joshi et al., 2003). Laboratory reared newly moulted third instar nymphs of $P$. solenopsis were collected and bioassays were conducted using standard leaf disc method (Anon., 1990). Ten solutions were made in distilled water. Leaf discs of 5 $\mathrm{cm}$ in diametre were cut from the unsprayed cotton leaves, washed and dried before using. These leaf discs were dipped in test solutions for $30 \mathrm{~s}$ with gentle agitation, and then were placed on tissue paper for drying, with the adaxial surface facing up. After drying, they were placed in $5 \mathrm{~cm}$ plastic Petri dishes that contained moist filter paper at their bottom to avoid desiccation. Five third instar nymphs were placed on each leaf disc. Each treatment was replicated ten times including controls. Mortality was assessed after 24 h, $48 \mathrm{~h}$ and 72 $\mathrm{h}$ of exposure to insecticides. Nymphs failed to show movements after a gentle touch were considered as dead insects.

\section{Field experiments}

A field trial was carried out at Pannikundu (Latitude-9' $49^{\circ} \mathrm{N}$ and Longitude $79^{\prime \prime} 01^{\circ} \mathrm{E}$ ) Madurai district of Tamil Nadu with cotton $c v$. SVPR 2 in randomized block design with a spacing of $60 \times 45 \mathrm{~cm}$ and $30 \mathrm{~m}^{2}$ plot size to evaluate the efficacy of botanicals against $P$. solenopsis during February 2008 to June 2008. The treatments evaluated in the field trial were neem seed kernel extract (NSKE) $5 \%$, pungam seed kernel extract (PSKE) 5\%, mahua seed kernel extract (MSKE) 5\%, neem oil (NO) 3\%, pungam oil (PO) 3\%, mahua oil (MO) 3\%, Fish Oil Rosin Soap (FORS) $2.5 \%$ and untreated check. Two sprays were given at 15 days interval. Population of mealy bug crawlers and adults per $5 \mathrm{~cm}$ shoot length from 10 randomly selected plants on $3,7,10$ and 14 day after treatment was recorded after each spray and mean per cent reduction of mealy bug population due to botanicals was estimated. Cost benefit ratio was also worked out to assess the economic feasibility. The same experiment was repeated one more time in the period of October 2008 to Febraury 2009 at same location to confirm bio-efficacy results of botanicals against $P$. solenopsis.

\section{Statistical analysis}

The data on numbers were transformed into square root values and per cent transformed into arc sine values before subjecting to statistical analysis (Gomez and Gomez, 1984). Analysis of variance was done in AGRESS and AGDATA packages. Critical difference values were calculated at five per cent probability level and treatment mean values were compared using Duncan's Multiple Range Test (DMRT) (Duncan, 1951). 


\section{Results and Discussion}

Bio efficacy of They inflicted significantly varied mortality levels from 19.2 to 50.7 per cent $24 \mathrm{~h}$ after treatment; from 26.8 to 63.4 per cent $48 \mathrm{~h}$ after treatment; and from 34.3 to 94.3 per cent $72 \mathrm{~h}$ after treatment. Irrespective of the treatments, highest per cent mortality of $P$. solenopsis was observed $72 \mathrm{~h}$ after treatment than 48 and $24 \mathrm{~h}$ after treatment.

Use of Fish oil rosin soap (FORS) @ 2.5g/l significantly contributed 50.7, 63.4 and 94.3 per cent mortality 24, 48 and $72 \mathrm{~h}$ after treatment respectively, which was the superior treatment. This was followed by the application of neem oil 3\% (46.6, 53.5 and 75.7 per cent mortality 24,48 and $72 \mathrm{~h}$ after treatment respectively); and neem seed kernel extract (NSKE) 5\% (32.9, 42.3 and 72.9 per cent mortality 24,48 and $72 \mathrm{~h}$ after treatment respectively). Bioassay of pungam oil $3 \%$ and pungam seed kernel extract (PSKE) 5\% revealed that they were next best treatments. However, use of mahua oil 3\% and mahua seed kernel extract (MSKE) 5\% did not contribute much reduction of population of $P$. solenopsis (Table 1).
Seven botanicals tested for their bioefficacy in the laboratory were also tested under field condition. Population of $P$. solenopsis prior to the use of botanicals was in a range of 27.4 to 30.7 crawler/adults per $5 \mathrm{~cm}$ apical shoot. Mean population of $P$. solenopsis after two sprays ranged from 5.5 to 37.2 due to various botanicals and untreated condition. Among the treatments, FORS @ 25g/l registered highest per cent reduction over control (85.3\% with 5.5 crawler/adults per $5 \mathrm{~cm}$ apical shoot).

Neem oil 3 per cent contributed 79.8 per cent reduction of $P$. solenopsis $(7.5$ crawler/adults per $5 \mathrm{~cm}$ apical shoot) followed by the NSKE 5 per cent $(74.9 \%$ population reduction and with 9.3 crawler/adults per $5 \mathrm{~cm}$ apical shoot) and was the next best treatment. Pungam oil and mahua oil also resulted in 69.2 per cent reduction (with 11.5 crawler/adults per $5 \mathrm{~cm}$ apical shoot) and 68.8 per cent reduction (11.6 crawler/adults per $5 \mathrm{~cm}$ apical shoot). However, use of PSKE and MSKE registered 63.6 (with 13.6 crawler/adults per $5 \mathrm{~cm}$ apical shoot) and 60.7 (14.6 crawler/adults per $5 \mathrm{~cm}$ apical shoot) per cent reduction of $P$. solenopsis respectively (Table 2).

Table.1 In vivo evaluation of plant extracts and FORS against $P$. solenopsis

\begin{tabular}{|c|c|c|c|}
\hline \multirow[t]{2}{*}{ Treatments } & \multicolumn{3}{|c|}{$\begin{array}{l}\text { Per cent mortality of crawlers and } \\
\text { adults at } h \text { after treatment* }\end{array}$} \\
\hline & $24 \mathrm{~h}$ & $48 \mathrm{~h}$ & $72 \mathrm{~h}$ \\
\hline Neem seed kernel extract (NSKE) 5\% & $32.9^{\mathrm{bc}}$ & $42.3^{\mathrm{c}}$ & $72.9^{\mathrm{b}}$ \\
\hline Pungam seed kernel extract (PSKE) 5\% & $20.6^{\mathrm{d}}$ & $33.8^{\mathrm{d}}$ & $45.7^{\mathrm{cd}}$ \\
\hline Mahua seed kernel extract (MSKE) 5\% & $19.2^{\mathrm{d}}$ & $26.8^{\mathrm{d}}$ & $34.3^{\mathrm{d}}$ \\
\hline Neem oil (NO) 3\% & $46.6^{\mathrm{a}}$ & $53.5^{\mathrm{b}}$ & $75.7^{\mathrm{b}}$ \\
\hline Pungam oil (PO) 3\% & $38.4^{\mathrm{b}}$ & $50.7^{\mathrm{b}}$ & $58.6^{\mathrm{c}}$ \\
\hline Mahua oil (MO) 3\% & $28.8^{\mathrm{c}}$ & $33.8^{\mathrm{d}}$ & $38.6^{\mathrm{d}}$ \\
\hline FORS $25 \mathrm{gm} / 1$ & $50.7^{\mathrm{a}}$ & $63.4^{\mathrm{a}}$ & $94.3^{\mathrm{a}}$ \\
\hline SEd \pm & 1.90 & 1.94 & 3.42 \\
\hline $\mathrm{CD}$ at $0.05 \%$ & 4.07 & 4.17 & 7.33 \\
\hline
\end{tabular}

*Mean of three replications

Values in a column are of arc sine $\sqrt{ } P$; Where $P$ is corrected per cent mortality; and original values are given In a column mean followed by same letter are not significantly different at $P>0.05$ as per DMRT 
Table.2 Field evaluation of plant extracts and FORS against $P$. solenopsis

\begin{tabular}{|c|c|c|c|c|c|c|}
\hline \multirow{3}{*}{ Treatments } & \multicolumn{6}{|c|}{ Population of mealy bug crawlers and adults per $5 \mathrm{~cm}$ apical shoot* } \\
\hline & \multicolumn{3}{|c|}{ Preliminary field trial } & \multicolumn{3}{|c|}{ Confirmatory field trial } \\
\hline & Pre-count & $\begin{array}{c}\text { Mean of after } \\
\text { two sprays }\end{array}$ & $\begin{array}{l}\text { Per cent reduction } \\
\text { over control* }\end{array}$ & Pre-count & $\begin{array}{l}\text { Mean of after } \\
\text { two sprays }\end{array}$ & $\begin{array}{l}\text { Per cent reduction } \\
\text { over control* }\end{array}$ \\
\hline Neem seed kernel extract (NSKE) $5 \%$ & 29.6 & $9.3^{\mathrm{c}}$ & 74.9 & 31.1 & $8.0^{\mathrm{b}}$ & 78.2 \\
\hline Pungam seed kernel extract (PSKE) 5\% & 28.5 & $13.6^{\mathrm{e}}$ & 63.6 & 31.9 & $12.2^{\text {cd }}$ & 66.9 \\
\hline Mahua seed kernel extract (MSKE) 5\% & 26.0 & $14.6^{\mathrm{e}}$ & 60.7 & 27.0 & $13.0^{\mathrm{d}}$ & 64.7 \\
\hline Neem oil (NO) 3\% & 30.7 & $7.5^{\mathrm{b}}$ & 79.8 & 29.1 & $7.4^{b}$ & 79.8 \\
\hline Pungam oil (PO) 3\% & 27.8 & $11.5^{\mathrm{d}}$ & 69.2 & 29.2 & $11.5^{\mathrm{c}}$ & 68.7 \\
\hline Mahua oil (MO) 3\% & 28.1 & $11.6^{\mathrm{d}}$ & 68.8 & 32.1 & $12.8^{\mathrm{cd}}$ & 65.3 \\
\hline FORS $25 \mathrm{gm} / 1$ & 27.4 & $5.5^{\mathrm{a}}$ & 85.3 & 29.6 & $5.9^{\mathrm{a}}$ & 84.0 \\
\hline Untreated check & 29.8 & $37.2^{\mathrm{f}}$ & - & 30.0 & $36.8^{\mathrm{e}}$ & - \\
\hline SEd \pm & \multirow{2}{*}{ NS } & 0.08 & - & \multirow{2}{*}{ NS } & 0.09 & - \\
\hline $\mathrm{CD}$ at $0.05 \%$ & & 0.18 & - & & 0.20 & - \\
\hline
\end{tabular}

* Mean of three replications

Values in column are $\sqrt{X}+0.5$ transformed values and original values are given

In a column means followed by a common letter are not significantly different $(P=0.05)$

Table.3 Evaluation of botanicals on yield of cotton and CBR under field condition

\begin{tabular}{|c|c|c|c|c|c|c|}
\hline \multirow[b]{2}{*}{ Treatments } & \multicolumn{3}{|c|}{ Preliminary field trial } & \multicolumn{3}{|c|}{ Confirmatory field trial } \\
\hline & Yield q/ha & $\begin{array}{l}\text { Per cent increase } \\
\text { over control }\end{array}$ & $\begin{array}{c}\text { Cost Benefit } \\
\text { Ratio }\end{array}$ & Yield (q/ha) & $\begin{array}{l}\text { Per cent increase } \\
\text { over control }\end{array}$ & $\begin{array}{c}\text { Cost Benefit } \\
\text { Ratio }\end{array}$ \\
\hline Neem seed kernel extract (NSKE) 5\% & 8.5 & 28.7 & $1: 1.6$ & 7.2 & 33.8 & $1: 1.4$ \\
\hline Pungam seed kernel extract (PSKE) 5\% & 7.6 & 14.7 & $1: 1.4$ & 6.5 & 20.2 & $1: 1.2$ \\
\hline Mahua seed kernel extract (MSKE) 5\% & 7.5 & 13.0 & $1: 1.4$ & 6.1 & 13.8 & $1: 1.2$ \\
\hline Neem oil (NO) 3\% & 8.8 & 33.1 & $1: 1.7$ & 7.8 & 44.9 & $1: 1.5$ \\
\hline Pungam oil (PO) 3\% & 7.7 & 16.2 & $1: 1.5$ & 6.7 & 24.5 & $1: 1.3$ \\
\hline Mahua oil (MO) 3\% & 7.7 & 15.7 & $1: 1.5$ & 6.3 & 17.6 & $1: 1.2$ \\
\hline FORS 25 gm/l & 10.7 & 61.4 & $1: 1.9$ & 9.1 & 68.1 & $1: 1.6$ \\
\hline Untreated check & 6.6 & - & - & 5.4 & - & - \\
\hline
\end{tabular}


Table 3 illustrates the effect of botanicals on the yield and cost benefit ratio. Kapas yield due to various treatments arrayed from 6.6 to $10.7 \mathrm{q} / \mathrm{ha}$. FORS treated plots registered highest kapas yield of $10.7 \mathrm{q} / \mathrm{ha}$ and registered 61.4 per cent increase over untreated. Application of neem oil and NSKE $5 \%$ however, contributed kapas yield of 8.8 and $8.5 \mathrm{q} / \mathrm{ha}$, respectively with respectively of 33.1 and 28.7 per cent increase over untreated condition. Pungam oil, mahua oil, PSKE and MSKE registered only lower kapas yield of 7.7, 7.7, 7.6 and $7.5 \mathrm{q} /$ ha with 16.2, 16.2, 14.7 and 13.9 per cent increase over control. Highest cost benefit ratio was estimated for FORS use (1:1.9) followed by Neem oil 3\% (1: 1.7); NSKE 5 per cent (1:1.6). The other botanicals such as Pungam oil, mahua oil, PSKE and MSKE contributed 1:1.5, 1:1.5, 1:1.4 and $1: 1.4$ respectively.

The same experiment was repeated to test verify the results. Table 2 shows the same pattern of efficacy of botanicals against $P$. solenopsis. The order of superiority of botanicals in minimizing the incidence of $P$. solenopsis was FORS @ 25g/l > Neem oil 3 per cent $>$ NSKE 5 per cent $>$ Pungam oil 3 per cent $>$ PSKE 5 per cent $>$ Mahua oil 3 per cent $>$ MSKE 5 per cent with respectively of 84.0, 79.8, 78.2, 68.7, 66.9, 65.3 and 64.7 per cent reduction.

Kapas yield ranged from 6.1 to $9.1 \mathrm{q} / \mathrm{ha}$ due to treatments and untreated check with 5.4 $q /$ ha. The order of superiority of botanicals in increasing the yield was FORS @ 25g/l > Neem oil 3 per cent $>$ NSKE 5 per cent $>$ Pungam oil 3 per cent $>$ PSKE 5 per cent $>$ Mahua oil 3 per cent $>$ MSKE 5 per cent with respectively of $1: 1.6,1: 1.5,1: 1.4,1: 1.3,1: 1.2$, $1: 1.2$ and $1: 1.2$ cost benefit ratio.

Present findings are in accordance with earlier results of Natarajan et al., (1991) who found that FORS 2 per cent, neem oil 0.5 per cent and mineral oil 2 per cent effectively suppressed the sap feeding insects of cotton when compared to synthetic insecticides. Similarly, Balasubramanian and Murali Baskaran (2000) stated that application of organic amendments like neem cake along with 75 per cent of $\mathrm{N}$ was found to be better in reducing the population of sucking pests of cotton. Pooja Sexena and Prabhat kumar (2007), evaluated the efficacy of ten herbal plants and the order of superiority was Thevetia nerifolia > Anona squamosa > Tephrosia vogelli > Caesalpinia crista > Pongamia glabra > Duranta repents > Tribulus terrestris > Ageratum conyzoides > Cleome icosandra > Uvaria neruum in controlling the mango mealybugs. The extract of $T$. nerifolia was most toxic to mango mealy bugs followed by $A$. squamosa, $T$. vogelli, $C$. crista, and $P$. glabra. Sprays of herbal extract derived from Nerium odorum and Bombax malabaricum (Pragat ${ }^{+}$) on mealy bugs (Maconellicoccus hirsutus) @ $1 \mathrm{ml} / \mathrm{l}$ at 4 days interval or spray with similar dose on consecutive days showed significant control of mealy bugs on grapes and increased the yield (Kulkarni et al., 2007).

\section{References}

Anonymous, 2005. Weekly pest scouting reports. Directorate General, Pest Warning and Quality Control of Pesticides, Punjab, Lahore, Pakistan.

Ayyangar, N. R and B. A. Nagasambangi. 1990. Role of botanicals in integrated pest management. In: Proc. Symp. Botanical pesticides in IPM, Rajamumdry, India, pp. 4-61.

Balasubraminian, A and R. K. Murali Baskaran. 2000. Influence of organic amendments and inorganic fertilizers on the incidence of sucking pest of cotton. Madras Agric. J., 87 (4-7): 359-361.

Bellows, T. S. 2001. Restoring population balance through natural enemy 
introductions. Biol. Contr., 21: 199-205.

David, H. 1981. Recent advances in sugarcane Entomology in India. In: Recent advances in Entomology in India. (Ed.) Ananthakrishnan, T. N., Loyola College, Madras, pp. 37-47.

Dhawan, A. K and G. S. Simwat. 2000. Evaluation of indoxacarb for the control of boll worm complex and its impact on population of sucking pests and beneficial arthropods in cotton ecosystem. Pestology. 24(7): 15-20.

Dhawan, A. K., J. Singh and A. S. Sidhu. 1980. Maconellicoccus sp. attacking Gossypium arboreum cotton in Punjab. Science and culture., 46: 258.

Dhawan. A. K., K. Singh, A. Anand and S. Sarika. 2009. Distribution of mealy bug, Phenacoccus solenopsis Tinsley in cotton with relation to weather factors in South-Western districts of Punjab. $J$. Ento. Res., 33 (1):27-35.

Jayaraj, S. 1999. NATP Training on IPM Technology assessment refinement and transfer in rice, groundnut and cotton based cropping system. Agricultural College and Research Institute, Madurai-625 104, pp. 65.

Kairon, M. S., P. Ramasundaram and M. V. Venugopalan, 1999. Cotton-potential for higher yields. The Hindu Survey of Indian Agriculture, Kasthuri and sons Ltd., Chennai, pp. 113-115.

Kao, S. S and C. C. Tzeg. 1990. Toxicity of insecticides to Cotesia plutellae, a parasitioid of diamond back moth. In: Dimaod back moth and other crucifer pests, (Eds.) Talekar, N. S. and T. D. Griggs. Asian vegetable Research and Development Centre, Shanhua, Taiwan, pp. 287-296.

Kulkarni, N. S., S. I. Sawant, S. D, Sawant and P. G. Adsule. 2007. Bio-efficacy of herbal extract derived from Nerium odorum and Bombax malabaricum (Praghat +) on mealy bugs
(Maconellicoccus hirsutus) and its effect on shelf life of Trichoderma treated grapes. Journal of Eco-friendly Agriculture, 2(1): 38-40.

Lim, J. L., C. K. Khoo and M. Xiann. 1986. The status and effectiveness of IKI7899 in controlling diamond back moth in the low lands and high lands of Malaysia. In: Diamond back moth and other crucifer pests, (Eds.) Talekar, N. S. and T. D. Griggs. Asian vegetable Research and Development centre, Shanhua, Taiwan, pp. 279-287.

Mani, M. 1989. A review of the pink mealybug Maconellicoccus hirsutus (Green). Insect Sci. Applic., 10: 157167.

Muralidharan, C. M and S. N. Badaya. 2000. Mealybug (Maconellicoccus hirsutus) (Pseudococcidae: Hemiptera) outbreak on herbaceum cotton (Gossypium herbaceum) in Waged cotton belt of Kachchh. Indian. J. Agric. Sci., 70: 705706.

Nagata, T. 1982. Insecticide resistance and chemical control of the brown plant hopper Nilaparvata lugens Stal. (Homoptera:Delphacidae). Bull Kyushu. Natnl. Agric. Exp. Stn., 22:49-164.

Natarajan, K., V. T. Sundaramurthy and P. Chidambaram. 1991. Usefulness of fish oil rosin soap in the management of whitefly and other sap feeding insects of cotton. Entomon, 16(3): 229-232.

Patel, I. S., D. A. Dodia and S. N. Patel. 1990. First record of Maconellicoccus hirsutus as a pest of pigeonpea (Cajanus cajan). Ind. J. of Agri. Sci., 60: 645 p.

Pooja Saxena and Prabhat Kumar. 2007. Herbal insecticidal approach to control mango mealy bug, Drosicha mangiferae (Hemiptera: Coccidae). Journal of EcoFriendly Agriculture 2(1):80-81.

Reissig, W. H., E. A. Heinrichs and S. L. Velencia. 1982. Insecticide induced resurgence of the brown plant hopper, 
Nilaparvata lugens on rice. Varieties with different levels of resistance. Environ. Entomol, 11(1): 165-168.

Singh, B and A. K. Dhaliwal. 1983. Pesticide contamination of fatty foods in developing countries. In: Pesticides: Their Ecological impact in developing countries, Commonwealth publishers, New Delhi, pp. 131-161.
Tewari, G. C and P. N. Krishnamoorthy. 1983. Effectiveness of newer insecticides against Epilachna beetle Henosepilachna vigintioctopunctata (Fab.) (Coleoptera: Coccinellidae) and their safety to natural enemy, Pediobius foveolatus Crawford (Hymenoptera: Eulophidae). Indian J. Agric, Sci., 53 (12):1068-1070.

\section{How to cite this article:}

Bharathi, K. and Muthukrishnan, N. 2017. Evaluation of Botanicals against Cotton Mealy Bug, Phenacoccus solenopsis Tinsley (Psuedococcidae: Hemiptera). Int.J.Curr.Microbiol.App.Sci. 6(12): 1055-1061. doi: https://doi.org/10.20546/ijcmas.2017.612.119 